OPEN ACCESS

Edited by:

Jeff Guptill,

Duke University, United States

Reviewed by:

Erdem Tüzün,

Istanbul University, Turkey

Sonia Berrih-Aknin,

Institut National de la Santé et de la

Recherche Médicale

(INSERM), France

John S. Yi,

Duke University, United States

*Correspondence:

Oliver A. Garden

ogarden@upenn.edu

tThese authors share senior authorship

Specialty section:

This article was submitted to Neuromuscular Diseases,

a section of the journal

Frontiers in Neurology

Received: 10 August 2020 Accepted: 23 November 2020 Published: 15 December 2020

Citation:

Wu Y, Luo J and Garden OA (2020) Immunoregulatory Cells in Myasthenia Gravis. Front. Neurol. 11:593431. doi: 10.3389/fneur.2020.593431

\section{Immunoregulatory Cells in Myasthenia Gravis}

\author{
Ying Wu, Jie Luo' and Oliver A. Garden*t
}

Department of Clinical Sciences and Advanced Medicine, School of Veterinary Medicine, University of Pennsylvania, Philadelphia, PA, United States

Myasthenia gravis (MG) is a T cell-dependent, B-cell mediated autoimmune disease caused by antibodies against the nicotinic acetylcholine receptor or other components of the post-synaptic muscle endplate at the neuromuscular junction. These specific antibodies serve as excellent biomarkers for diagnosis, but do not adequately substitute for clinical evaluations to predict disease severity or treatment response. Several immunoregulatory cell populations are implicated in the pathogenesis of MG. The immunophenotype of these populations has been well-characterized in human peripheral blood. $\mathrm{CD}^{+}{ }^{+} \mathrm{FoxP}^{+}$regulatory $\mathrm{T}$ cells (Tregs) are functionally defective in MG, but there is a lack of consensus on whether they show numerical perturbations. Myeloidderived suppressor cells (MDSCs) have also been explored in the context of MG. Adoptive transfer of CD4+FoxP3+ Tregs or MDSCs suppresses ongoing experimental autoimmune MG (EAMG), a rodent model of MG, suggesting a protective role of both populations in this disease. An imbalance between follicular Tregs and follicular T helper cells is found in untreated MG patients, correlating with disease manifestations. There is an inverse correlation between the frequency of circulating $\mathrm{IL}-10-$ producing $\mathrm{B}$ cells and clinical status in MG patients. Taken together, both functional and numerical defects in various populations of immunoregulatory cells in EAMG and human MG have been demonstrated, but how they relate to pathogenesis and whether these cells can serve as biomarkers of disease activity in humans deserve further exploration.

Keywords: myasthenia gravis, regulatory T cells (Treg), follicular, circulating, regulatory B cells (Breg)

\section{INTRODUCTION}

Myasthenia gravis (MG) is a chronic autoimmune disease characterized by muscle weakness and fatigue $(1,2)$. Pathogenic autoantibodies in MG target components of the post-synaptic muscle endplate located at the neuromuscular junction, impairing neuromuscular transmission (3). A vast majority of patients have antibodies against muscle nicotinic acetylcholine receptors (AChRs); a minority have antibodies against muscle-specific tyrosine kinase (MuSK) or lowdensity lipoprotein receptor-related protein 4 (LRP4) $(2,4)$. MG patients without detectable autoantibodies are referred to as having seronegative MG. Apart from autoantibody specificity, MG can be subclassified based on age of onset, clinical presentation, and thymic histopathology $(3,5)$. Heterogeneity of the disease makes predicting prognosis challenging $(1,6)$. Conventional treatment options, including symptomatic treatments and general immunosuppression, can help many but not all patients (5). Durable remission remains improbable, and chronic treatment with high doses of non-specific immunosuppressive drugs is usually necessary to maintain disease remission. Current therapeutic approaches lack specificity and are associated with a number of side effects 
(1, 5). Identifying new biomarkers that can predict disease progression and treatment response and can be practically applied in clinical studies is highly desirable for the development of more specific and better tolerated treatments for MG patients.

The primary outcome measure of choice in MG trials is so far focused on the effect of clinical signs and symptoms (7). Single fiber electromyography represents the most robust biomarker of neuromuscular transmission, but is limited by factors related to accuracy, reproducibility, and availability of technical expertise (8). Antibody titers to AChR or MuSK have been used as a marker of the therapeutic response, but the correlation of this measure with disease severity has not been confirmed (9-12). Attempts to identify new biomarkers face challenges. Serum metabolomic profiling distinguishes patients with anti-AChR antibody-seropositive (AChR+) MG from those without (13), but whether metabolic analysis can predict therapeutic outcome remains to be explored.

Immunoregulatory cells operate in the periphery to modulate immune responses, especially those of autoreactive $\mathrm{T}$ and $\mathrm{B}$ cells that have escaped central tolerance (14-17). They are implicated in the pathogenesis of a variety of autoimmune diseases, including MG (18-21). Regulatory cells can be readily phenotyped and isolated on the basis of surface antigens and have been reported in a number of studies of MG (22-36). This review summarizes current knowledge of regulatory cells in $\mathrm{MG}$, including their potential implication in pathogenesis.

\section{IMMUNOREGULATORY CELLS}

Immunoregulatory cell populations are diverse in their lineage and phenotype. Regulatory cells in the lymphoid lineage are represented by regulatory $\mathrm{T}$ (Tregs) (37-39), regulatory B (Bregs) $(20,40)$, and regulatory natural killer cells (41-43), while those in the myeloid lineage comprise myeloid-derived suppressor cells (MDSCs) (44-47), regulatory dendritic cells (DCs) (48-50), regulatory macrophages (51-53), regulatory neutrophils (54-57), and regulatory eosinophils $(58,59)$.

\section{Regulatory T Cells CD4 ${ }^{+}$FoxP3 $^{+}$Regulatory T Cells}

As a principal player in peripheral tolerance, Tregs are among the most widely studied of the regulatory cells (38, 39). In humans and mice, Tregs are characterized as suppressive $\mathrm{T}$ cells, predominantly $\mathrm{CD} 4^{+}$, that constitutively express CD25 and the transcription factor forkhead box P3 (FoxP3) (37, 60). Human $\mathrm{CD}^{+}{ }^{+} \mathrm{CD} 25^{+} \mathrm{FOXP}^{+} \mathrm{T}$ cells are heterogeneous and have been labeled by additional surface antigens such as CD127, CD45RA/RO, and sialyl lewis $\mathrm{x}$ (CD15s) to further delineate naïve Tregs as $\mathrm{CD} 25^{+} \mathrm{CD} 127^{\text {low }}{ }^{\mathrm{CD}} 45 \mathrm{RA}^{+}$FoxP3 ${ }^{\text {low }}$, activated Tregs as $\mathrm{CD} 25^{\text {high }} \mathrm{CD} 127^{\text {low }} \mathrm{CD} 45 \mathrm{RA}^{-}$FoxP3 $3^{\text {high }}$, highly suppressive Tregs as $\mathrm{CD}_{2} 5^{+} \mathrm{CD} 127^{\text {low }} \mathrm{CD} 45 \mathrm{RA}^{-} \mathrm{CD} 15 \mathrm{~s}^{+} \mathrm{FoxP}^{+}$, and non-suppressive $\mathrm{T}$ cells (also known as "non-Tregs") as $\mathrm{CD} 25^{+} \mathrm{CD} 127^{\text {low }}{ }^{\mathrm{CD}} 45 \mathrm{RA}^{-}$FoxP3 ${ }^{\text {low }}$ (61-66). Tregs have also been identified in domestic animal species, including dogs and cats (67-72), which are gaining traction as spontaneous models for many human diseases (73-79). Our previous work has revealed a conserved transcriptomic signature of Tregs among humans, mice, and dogs, vindicating the view that these cells are phenotypically and functionally related between these mammalian taxa. Thirty-one consensus transcripts were highly expressed in Tregs of all three species in comparison with their conventional $\mathrm{T}$ cell counterparts. Of the 31 consensus transcripts, six encode the Treg signature molecules CD25, FoxP3, IL-10, Helios, Galectin 3, and T-cell immunoreceptor with immunoglobulin and immunoreceptor tyrosine-based inhibitory motif domains (TIGIT) (68). Many other $\mathrm{T}$ cell subsets possess regulatory function, including CD8 ${ }^{+} \mathrm{T}$ cells $(80-$ $82)$, type 1 regulatory $\mathrm{T}(\mathrm{Tr} 1)$ cells $(83,84), \gamma \delta \mathrm{T}$ cells $(85,86)$, and invariant natural killer $\mathrm{T}$ (iNKT) cells $(87,88)$. However, $\mathrm{CD}^{+}{ }^{+}$FoxP3 ${ }^{+}$Tregs (Figure $\mathbf{1 A}$ and Table 1) dominate research in this field $(17,21,89)$.

A number of studies have characterized Tregs in human AChR+ MG patients based on CD25 and/or FoxP3 expression $(22,23,25-32,35)$. A majority of reports found no alteration in the frequency or absolute number of Tregs isolated from either peripheral blood or thymus of MG patients in comparison with those from healthy subjects $(22,23,25,26,28,29,31,32,35)$. However, some studies made disparate observations. In the study of Fattorossi et al. (30), the number of circulating Tregs in untreated MG patients was lower than those in healthy subjects and MG patients treated with prednisone and azathioprine, which suggested that the clinical benefit of immunosuppressive therapy may in part be attributable to increasing Treg numbers. These authors also found that although thymectomy transiently inhibited the increase in frequency of circulating Tregs following immunotherapy, circulating Tregs in these patients eventually returned to a level similar to those of patients treated with immunotherapy without thymectomy. These data suggest that circulating Treg recovery during immunotherapy might be independent of the thymus. Li et al. (27) found lower frequency of circulating $\mathrm{CD}^{+}$Tregs, but unaltered frequency of $\mathrm{CD}^{+}$ Tregs, in MG patients than in healthy controls. However, further studies with subgroup analysis is needed to discern the difference between the subtypes of MG and the effect of medications. In contrast to the lack of consensus on numerical perturbations of Tregs in MG, impaired function of Tregs has been consistently demonstrated by in vitro functional analysis $(22,23,26,28,29,32,35)$. The dysfunction has been associated with attenuated FoxP3 expression, given the pivotal role of FoxP3 in Treg development and function (90-92). One study suggested a link between decreased FoxP3 expression and lowered phosphorylation of signal transducer and activator of transcription-5 (STAT5) (35). Furthermore, Luther et al. (26) reported that Tregs from prednisolone-treated MG patients had enhanced suppressive function in vitro compared to those from untreated patients, suggesting that prednisolone might augment Treg function. This result accords with the findings of Fattorossi et al. (30), which also showed augmentation of Treg numbers during immunosuppressive medication. Together, these data indicate a potential role of immunosuppressive therapy in restoring Treg number and function. However, both studies only compared treated and untreated patients at a single time point. A longitudinal study is needed to address this hypothesis. In 


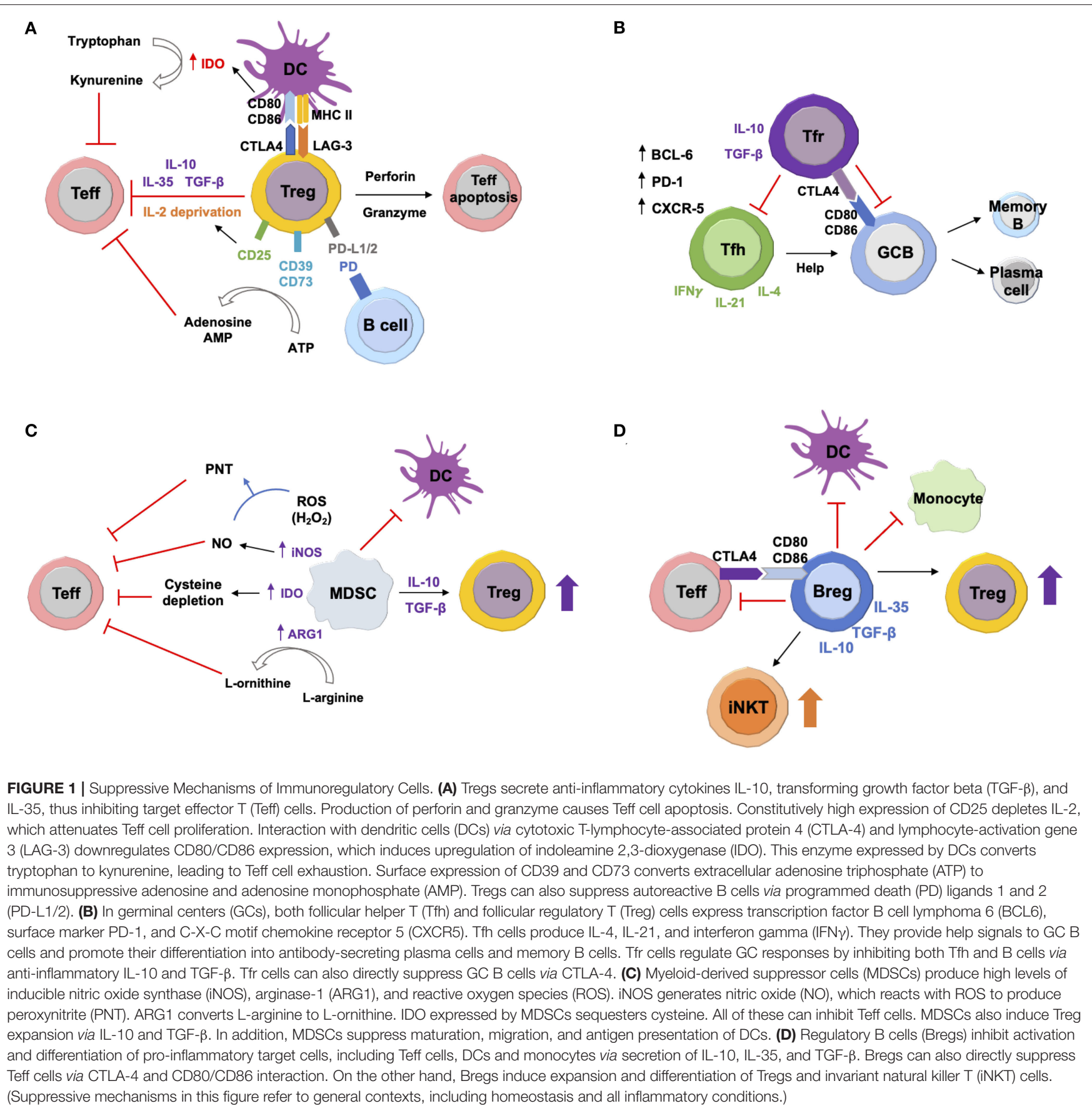

addition, stability of Treg function is likely to be influenced by the inflammatory environment in MG. For instance, the inflammatory cytokine tumor necrosis factor alpha (TNF- $\alpha$ ) negatively modulates human $\mathrm{CD} 4{ }^{+} \mathrm{CD} 25^{\text {high }}$ Treg function (93). A more recent study showed that loss of FoxP3 expression by human Tregs mediated by TNF- $\alpha$ depends on the FoxP3 complex component Deleted in Breast Cancer 1 (DBC1) (94).

Studies on experimental autoimmune MG (EAMG) in rodents have provided additional insight into the role of Tregs. Aricha et al. (34) showed that myasthenic rats had a lower frequency of circulating $\mathrm{CD} 4{ }^{+} \mathrm{CD} 25^{\text {high }} \mathrm{FoxP} 3^{+} \mathrm{T}$ cells than healthy controls, while Nessi et al. (24) found no difference in frequency of $\mathrm{CD} 4^{+} \mathrm{CD} 25^{+/ \text {high }} \mathrm{T}$ cells in either spleens or lymph nodes between rats with EAMG and healthy controls. Both groups also investigated the therapeutic effect of passive transfer of Tregs. Aricha et al. $(33,34)$ reported that adoptive transfer of in vitro-induced polyclonal Tregs from either healthy or EAMG donors suppressed ongoing EAMG. Nessi et al. (24) found that $\mathrm{CD} 4{ }^{+} \mathrm{CD} 25^{+} \mathrm{T}$ cells isolated from naïve rats prevented the induction of EAMG, but did not suppress established disease. 
This observation might reflect insufficient numbers of activated Tregs among administered $\mathrm{CD} 4{ }^{+} \mathrm{CD} 25^{+} \mathrm{T}$ cells.

Only a limited number of studies have investigated $\mathrm{T}$ cell populations in peripheral blood of human patients with MuSK+ MG. Yi et al. (95) found that CD4 ${ }^{+} \mathrm{T}$ cells exhibit enhanced inflammatory Th1 and Th17 responses in MuSK+ MG, although no difference was found in either frequencies or CD39 expression of FoxP3 ${ }^{+}$Tregs between MuSK+ MG and healthy controls, suggesting that increased pro-inflammatory $\mathrm{T}$ cell responses were not attributed to numerical or functional defects of Tregs. The same group (96) also reported that tacrolimus, an immunosuppressant for AChR+ MG, inhibited Th1 and Th17 responses, and reduced Treg frequencies of in vitro cultured peripheral blood mononuclear cells (PBMCs) from MuSK+ MG patients. Reuveni et al. (97) reported that a mouse model of MuSK+ EAMG had decreased Treg frequencies and FoxP3 expression, the latter of which was restored by oral administration of recombinant MuSK protein.

In summary, AChR $+\mathrm{MG}$ is associated with functional defects of Tregs. Adoptive transfer of Tregs derived from either healthy rats or myasthenic rats can attenuate EAMG. In contrast, the pathogenic role of Tregs remains unclear in $\mathrm{MuSK}+\mathrm{MG}$.

\section{Follicular Regulatory T Cells}

Follicular regulatory $\mathrm{T}$ (Tfr) cells (Figure 1B and Table 1) have emerged as a unique subset of $\mathrm{CD}^{+}$Tregs that negatively regulate the proliferation of follicular helper $\mathrm{T}$ (Tfh) and B cells in germinal centers (GCs) $(98,99)$. Both Tfr and Tfh cells express common GC-associated antigens, including transcription factor B cell lymphoma 6 (BCL6), chemokine receptor CXCR5, programmed death-1 (PD-1), and inducible T-cell co-stimulator (ICOS) (100-103). However, unlike Tfh cells, Tfr cells concurrently express Treg-characteristic markers such as CD25, FoxP3, glucocorticoid-induced tumor necrosis factor receptor (GITR), and cytotoxic T-lymphocyte antigen 4 (CTLA-4) $(100,101)$. Tfr and Tfh cells regulate humoral immunity in opposite directions (104). Imbalance between these two populations dysregulates production of autoantibodies, promoting pathogenic autoimmunity $(105,106)$. Tfr and Tfh cells primarily reside in GCs (98). However, some studies have identified counterpart $\mathrm{CD} 4^{+} \mathrm{T}$ cell subsets in peripheral blood, facilitating investigation of their pathogenic potential in the context of autoimmunity, including MG $(107,108)$.

The frequency of a population of $\mathrm{CD} 4^{+} \mathrm{CXCR} 5^{+} \mathrm{T}$ cells was higher in the peripheral blood of untreated MG patients than in that of healthy controls (109). The cell frequency was positively correlated with disease severity. Thymectomy followed by glucocorticoid therapy reduced $\mathrm{CD} 4^{+} \mathrm{CXCR} 5^{+} \mathrm{T}$ cell frequency in these myasthenic patients to the control level (109). In a similar observation, an increased frequency of circulating Tfh cells, defined as $\mathrm{CD} 4^{+} \mathrm{CXCR}^{+} \mathrm{PD}-1^{\text {high }} / \mathrm{ICOS}^{\text {high }}$ cells, was demonstrated in $\mathrm{MG}$ patients in comparison to healthy subjects (110). The study also showed a positive correlation between circulating Tfh cell frequency and serum anti-AChR antibody titer in these patients (110). In line with these clinical studies, EAMG mice also have a higher frequency of splenic $\mathrm{CD} 4{ }^{+} \mathrm{CXCR}^{+} \mathrm{PD}-1^{+}$Tfh cells than controls, and their Tfh cell frequency is positively correlated with the concentration of antiAChR antibodies in serum (111). All these findings collectively suggest that the frequency of circulating Th cells reflects disease activity in AChR+ MG. However, a shortcoming in these studies is the lack of distinction of Tfr and Tfh cells amongst circulating follicular T cells.

Three recent studies showed that AChR + MG patients had a lower frequency of circulating Tfr cells, but a higher frequency of circulating Tfh cells than healthy controls, suggesting a link between the imbalance of the Tfr/Tfh ratio and disease manifestations $(107,112,113)$. The Tfr/Tfh ratio showed an inverse correlation with AChR+ MG severity, and the imbalance was restored by steroid and cyclophosphamide therapy (107). Taken together, the ratio between circulating Tfr and Tfh cells is likely to predict the development of AChR+ MG. Similarly, a higher Tfh/Tfr ratio was found in MuSK+ MG patients, accompanying increased frequencies of Th17-producing Tfh cells and higher Tfh-promoted IgG synthesis (114). The pathological roles of $\mathrm{Tfr}$ and $\mathrm{Tfh}$ populations in MG need to be further investigated in animal models.

\section{Other Regulatory Cell Populations}

In contrast to Tregs, limited information is available on other regulatory populations in MG. To date, only MDSCs and Bregs have been examined in MG.

\section{Myeloid-Derived Suppressor Cells}

MDSCs (Figure 1C and Table 1) are a heterogeneous population of immature myeloid cells that accumulate in cancers and other diseases involving chronic inflammation (45). These cells suppress $\mathrm{T}$ cell responses and contribute to tumor progression and metastasis, emerging as a promising therapeutic target in cancer (46). MDSCs comprise two major subsets, polymorphonuclear (PMN)- and monocytic (M)-MDSCs (47). They are distinguished from conventional neutrophils or monocytes by surface antigens and density $(44,47)$. In humans, PMN-MDSCs are identified as $\mathrm{CD} 11 \mathrm{~b}^{+} \mathrm{CD} 14^{-} \mathrm{CD} 15^{+} \mathrm{CD} 33^{+}$or

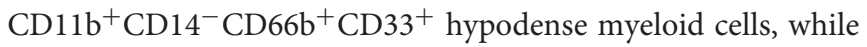
M-MDSCs are identified as $\mathrm{CD} 11 \mathrm{~b}^{+} \mathrm{CD} 14^{+} \mathrm{CD} 15^{-} \mathrm{CD} 33^{+} \mathrm{HLA}-$ $\mathrm{DR}^{-/ \text {low }}$ hypodense myeloid cells; both populations are found in the PBMC fraction after density gradient separation (44). The murine counterparts of PMN- and M-MDSCs are $\mathrm{CD} 11 \mathrm{~b}^{+} \mathrm{Ly}_{6 \mathrm{G}}{ }^{+} \mathrm{Ly}_{6 C^{\text {low }}}$ and $\mathrm{CD} 11 \mathrm{~b}^{+} \mathrm{Ly}_{6 \mathrm{G}}{ }^{-} \mathrm{Ly}_{6 \mathrm{C}}{ }^{\text {high }}$ cells, respectively (44). Our previous work has identified functional equivalents of these subsets in dogs based on the expression of CADO48A and CD14 (115). The role of MDSCs has been investigated in a variety of autoimmune diseases (116-122). The ability of in vitro generated MDSCs to suppress EAMG has been investigated in mice (123). Adoptive transfer of MDSCs improved muscle weakness, reducing both serum antiAChR IgG levels and complement deposition at the endplates in EAMG mice. Splenocytes from MDSC-treated mice had a lower production of IFN- $\gamma$ and IL-17 in vitro, demonstrating reduced Th1 and Th17 responses. MDSCs also directly inhibited pre-activated B cells both in vitro and in vivo. These results suggest that MDSCs suppress ongoing EAMG by inhibiting both autoreactive T and B cells (123). 
TABLE 1 | Summary of Immunoregulatory Cells in AChR+ MG.

\begin{tabular}{|c|c|c|c|c|c|}
\hline Cell types & Markers* & Cytokines* & Target cells* & $\begin{array}{l}\text { Association with pathogenesis } \\
\text { in MG }\end{array}$ & References \\
\hline $\mathrm{CD}^{+}{ }^{+} \mathrm{FoxP}^{+}{ }^{+}$Treg & $\begin{array}{l}\text { CD25 } 5^{+} \text {or CD25 high , FoxP3, } \\
\text { CTLA-4 (CD152), GITR, LAG-3, } \\
\text { Neuropilin-1, CD127-/low, Sialyl } \\
\text { Lewis } \times \text { (CD15s) }\end{array}$ & $\begin{array}{l}\text { IL-10, TGF- } \beta \text {, } \\
\text { IL-35 }\end{array}$ & $\begin{array}{l}\text { Teff cells, APCs, B } \\
\text { cells }\end{array}$ & $\begin{array}{l}\text { - Functional defect is associated } \\
\text { with reduced FoxP3 expression and } \\
\text { MG pathogenesis; } \\
\text { - Decreased FoxP3 expression } \\
\text { correlates with attenuated STAT5 } \\
\text { signaling; } \\
\text { - Numerical correlation remains } \\
\text { controversial; } \\
\text { - Adoptive transfer treats EAMG }\end{array}$ & $\begin{array}{l}(22-35,37,61 \\
64,130)\end{array}$ \\
\hline Tfh & $\mathrm{CD}^{+}{ }^{+} \mathrm{CXCR} 5^{+} \mathrm{PD}-1^{+} / \mathrm{ICOS}^{+}$ & $\begin{array}{l}\text { IL-21, IL-4, } \\
\text { IL-17, IFN } \gamma\end{array}$ & GC B cells & $\begin{array}{l}\text { - Cell frequency positively correlates } \\
\text { with disease severity; } \\
\text { - Tfr/Tfh ratio inversely correlates } \\
\text { with disease severity }\end{array}$ & $(102-113)$ \\
\hline PMN-MDSC & 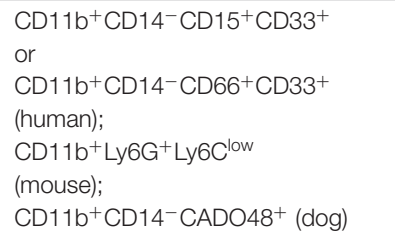 & IL-10, TGF- $\beta$ & $\begin{array}{l}\text { Teff cells; DCs; } \\
\text { macrophages }\end{array}$ & $\begin{array}{l}\text { Adoptive transfer of MDSC treats } \\
\text { EAMG in mice }\end{array}$ & $\begin{array}{l}(44-47,115, \\
123)\end{array}$ \\
\hline M-MDSC & 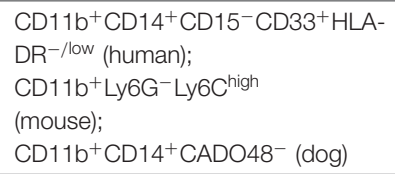 & IL-10, TGF- $\beta$ & $\begin{array}{l}\text { Teff cells; DCs; } \\
\text { macrophages }\end{array}$ & $\begin{array}{l}\text { Adoptive transfer of MDSC treats } \\
\text { EAMG in mice }\end{array}$ & $\begin{array}{l}(44-47,115, \\
123)\end{array}$ \\
\hline
\end{tabular}

*Markers, cytokines, and target cells refer to general contexts, including homeostasis and all inflammatory conditions.

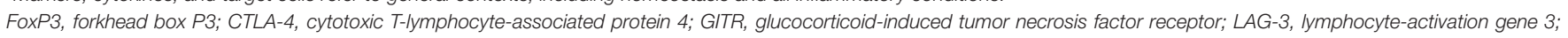

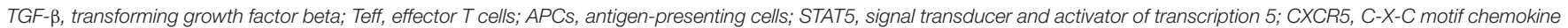
receptor 5; PD-1, programmed death 1; ICOS, inducible T cell co-stimulator; IFN $\gamma$, interferon gamma; GC, germinal center; DCs, dendritic cells; iNKTs, invariant natural killer T cells.

\section{Regulatory B Cells}

Bregs (Figure 1D and Table 1) have been identified in humans and mice as a heterogeneous population of immunosuppressive $\mathrm{B}$ cells that inhibit pro-inflammatory responses predominantly by means of IL-10 synthesis $(40,124)$. However, intracellular staining for IL-10 precludes functional studies of Bregs, prompting Breg isolation using surface markers such as CD19, CD38, CD24, CD1d, and CD27 (20, 40). Breg frequency and function are negatively correlated with disease activity of several autoimmune disorders, such as systemic lupus erythematosus (SLE), rheumatoid arthritis (RA), and multiple sclerosis (MS) (20). Two studies have shown reduced frequency and function of circulating Bregs in untreated AChR + MG patients compared with healthy controls $(36,125)$. The proportion of circulating Bregs can be restored by thymectomy, but not by steroid therapy (125). A subset of Bregs, namely IL-10-producing B (B10) cells (126), repopulated at a faster rate in the patients with a favorable response to rituximab than in those with a poor response (36). In addition, Guptill et al. (127) also reported a reduction of B10 frequencies in MuSK+ MG patients compared to healthy controls. These results together suggest an immunopathogenic role of diminished Bregs in both $\mathrm{AChR}+$ and MuSK+ MG. Adoptive transfer of Bregs has not yet been reported in MG. However, Bregs transferred into mice with experimental autoimmune encephalomyelitis induced FoxP3 ${ }^{+}$ Tregs and Tr1 cells, and correlated with disease remission (128). This observation suggests that Bregs might hold promise as an adoptive cellular therapy for MG.

\section{DISCUSSION}

Current data suggest that immunoregulatory cells may play significant roles in the pathogenesis of $\mathrm{MG}$. In $\mathrm{AChR}+\mathrm{MG}$ patients, these populations show either functional defects $\left(\mathrm{CD} 4^{+} \mathrm{FoxP}^{+}\right.$Tregs) or numerical deficiency (Tfr), or both 
(Bregs). They can be readily isolated from patients' peripheral blood and characterized by flow cytometry. Performing functional assays in the current routine clinical setting can be challenging, while numerical analysis of circulating Tfr, Tfh, or Breg cells shows promising utility in clinical practice. However, several drawbacks need to be addressed before these assays may be translated for clinical use.

First, current studies have extensively examined AChR+ MG cases, leaving a scarcity of knowledge for the less common, but equally debilitating, MuSK + , LRP4+, and seronegative phenotypes of $\mathrm{MG}$ - although the nature of a small subpopulation of a rare disease makes such studies challenging. Second, the current studies have treated all AChR+ MG patients as a homogeneous group, calling into question whether these assays can further differentiate subsets of MG patient groups, including classification based on clinical presentation, age of onset, gender, and thymic histopathology. Third, the low frequencies of circulating Tfr and Breg cells are a significant obstacle in accurate quantification of these populations. An

\section{REFERENCES}

1. Mantegazza R, Bernasconi P, Cavalcante P. Myasthenia gravis: from autoantibodies to therapy. Curr Opin Neurol. (2018) 31:517-25. doi: 10.1097/WCO.0000000000000596

2. Ludwig RJ, Vanhoorelbeke K, Leypoldt F, Kaya Z, Bieber K, McLachlan SM, et al. Mechanisms of autoantibody-Induced Pathology. Front Immunol. (2017) 8:603. doi: 10.3389/fimmu.2017.00603

3. Gilhus NE, Tzartos S, Evoli A, Palace J, Burns TM, Verschuuren J. Myasthenia gravis. Nat Rev Dis Primers. (2019) 5:30. doi: 10.1038/s41572-019-0079-y

4. Vincent A, Huda S, Cao M, Cetin H, Koneczny I, Rodriguez Cruz PM, et al. Serological and experimental studies in different forms of myasthenia gravis. Ann N Y Acad Sci. (2018) 1413:143-53. doi: 10.1111/nyas. 13592

5. Gilhus NE, Verschuuren JJ. Myasthenia gravis: subgroup classification and therapeutic strategies. Lancet Neurol. (2015) 14:1023-36. doi: 10.1016/S1474-4422(15)00145-3

6. Gilhus NE, Verschuuren JJ. Autoimmune myasthenia gravis: emerging clinical and biological heterogeneity. Lancet Neurol. (2009) 8:47590. doi: 10.1016/S1474-4422(09)70063-8

7. Barnett C, Herbelin L, Dimachkie MM, Barohn RJ. Measuring clinical treatment response in myasthenia gravis. Neurol Clin. (2018) 36:33953. doi: 10.1016/j.ncl.2018.01.006

8. Meriggioli MN, Rowin J. Single fiber EMG as an outcome measure in myasthenia gravis: results from a double-blind, placebo-controlled trial. J Clin Neurophysiol. (2003) 20:3825. doi: 10.1097/00004691-200309000-00011

9. Benatar M, Sanders DB, Burns TM, Cutter GR, Guptill JT, Baggi F, et al. Recommendations for myasthenia gravis clinical trials. Muscle Nerve. (2012) 45:909-17. doi: 10.1002/mus.23330

10. Lindstrom JM, Seybold ME, Lennon VA, Whittingham S, Duane DD. Antibody to acetylcholine receptor in myasthenia gravis. Prevalence, clinical correlates, and diagnostic value. Neurology. (1976) 26:10549. doi: 10.1212/WNL.26.11.1054

11. Sanders DB, Burns TM, Cutter GR, Massey JM, Juel VC, Hobson-Webb $\mathrm{L}$, et al. Does change in acetylcholine receptor antibody level correlate with clinical change in myasthenia gravis? Muscle Nerve. (2014) 49:4836. doi: 10.1002/mus. 23944

12. Tzartos SJ, Seybold ME, Lindstrom JM. Specificities of antibodies to acetylcholine receptors in sera from myasthenia gravis patients measured by monoclonal antibodies. PNAS. (1982) 79:188-92. doi: 10.1073/pnas.79.1.188 alternative is to analyze the characteristic gene expression of these populations by qRT-PCR assay. Furthermore, antigen-specific regulatory cells may closely correlate with disease severity in MG, assessed using MHC-peptide tetramers or fluorescently-labeled antigens (129).

In conclusion, numerical measures of circulating Tfr, Tfh and B10 cells appear to correlate with disease activity of $\mathrm{AChR}+\mathrm{MG}$; however, none of these populations shows sufficient sensitivity or specificity to serve as a biomarker for the disease. Mechanistic insight into the roles of immunoregulatory cells in the pathogenesis of MG will enable the development of more targeted therapies for this debilitating autoimmune disease in the future.

\section{AUTHOR CONTRIBUTIONS}

YW conceptualized and drafted the manuscript. OG and JL critically reviewed the manuscript. All authors contributed to the article and approved the final version.

13. Blackmore D, Siddiqi Z, Li L, Wang N, Maksymowych W. Beyond the antibodies: serum metabolomic profiling of myasthenia gravis. Metabolomics. (2019) 15:109. doi: 10.1007/s11306-019-1571-9

14. Lee S, Ko Y, Kim TJ. Homeostasis and regulation of autoreactive B cells. Cell Mol Immunol. (2020) 17:561-9. doi: 10.1038/s41423-020-0445-4

15. Mueller DL. Mechanisms maintaining peripheral tolerance. Nat Immunol. (2010) 11:21-7. doi: 10.1038/ni.1817

16. Sakaguchi S, Yamaguchi T, Nomura T, Ono M. Regulatory $\mathrm{T}$ cells and immune tolerance. Cell. (2008) 133:775-87. doi: 10.1016/j.cell.2008.05.009

17. Sharma A, Rudra D. Emerging functions of regulatory t cells in tissue homeostasis. Front Immunol. (2018) 9:883. doi: 10.3389/fimmu.2018.00883

18. Dominguez-Villar M, Hafler DA. Regulatory T cells in autoimmune disease. Nat Immunol. (2018) 19:665-73. doi: 10.1038/s41590-018-0120-4

19. Danikowski KM, Jayaraman S, Prabhakar BS. Regulatory T cells in multiple sclerosis and myasthenia gravis. J Neuroinflammation. (2017) 14:117. doi: 10.1186/s12974-017-0892-8

20. Mauri C, Menon M. Human regulatory B cells in health and disease: therapeutic potential. J Clin Invest. (2017) 127:772-9. doi: 10.1172/JCI85113

21. Romano M, Fanelli G, Albany CJ, Giganti G, Lombardi G. Past, present, and future of regulatory $\mathrm{T}$ cell therapy in transplantation and autoimmunity. Front Immunol. (2019) 10:43. doi: 10.3389/fimmu.2019.00043

22. Thiruppathi M, Rowin J, Li Jiang Q, Sheng JR, Prabhakar BS, Meriggioli MN. Functional defect in regulatory T cells in myasthenia gravis. Ann N Y Acad Sci. (2012) 1274:68-76. doi: 10.1111/j.1749-6632.2012.06840.x

23. Thiruppathi M, Rowin J, Ganesh B, Sheng JR, Prabhakar BS, Meriggioli MN. Impaired regulatory function in circulating CD4(+)CD25(high)CD127(low/-) $\mathrm{T}$ cells in patients with myasthenia gravis. Clin Immunol. (2012) 145:209-23. doi: 10.1016/j.clim.2012.09.012

24. Nessi V, Nava S, Ruocco C, Toscani C, Mantegazza R, Antozzi C, et al. Naturally occurring CD4+CD25+ regulatory $\mathrm{T}$ cells prevent but do not improve experimental myasthenia gravis. J Immunol. (2010) 185:565667. doi: 10.4049/jimmunol.0903183

25. Matsui N, Nakane S, Saito F, Ohigashi I, Nakagawa Y, Kurobe H, et al. Undiminished regulatory $\mathrm{T}$ cells in the thymus of patients with myasthenia gravis. Neurology. (2010) 74:816-20. doi: 10.1212/WNL.0b013e3181d31e47

26. Luther C, Adamopoulou E, Stoeckle C, Brucklacher-Waldert V, Rosenkranz D, Stoltze L, et al. Prednisolone treatment induces tolerogenic dendritic cells and a regulatory milieu in myasthenia gravis patients. J Immunol. (2009) 183:841-8. doi: 10.4049/jimmunol.0802046

27. Li X, Xiao BG, Xi JY, Lu CZ, Lu JH. Decrease of CD4(+)CD25(high)Foxp3(+) regulatory $\mathrm{T}$ cells and elevation of 
CD19(+)BAFF-R(+) B cells and soluble ICAM-1 in myasthenia gravis. Clin Immunol. (2008) 126:180-8. doi: 10.1016/j.clim.2007.10.001

28. Kohler S, Keil TOP, Hoffmann S, Swierzy M, Ismail M, Ruckert JC, et al. CD4(+) FoxP3(+) T regulatory cell subsets in myasthenia gravis patients. Clin Immunol. (2017) 179:40-6. doi: 10.1016/j.clim.2017.03.003

29. Gradolatto A, Nazzal D, Truffault F, Bismuth J, Fadel E, Foti M, et al. Both Treg cells and Tconv cells are defective in the myasthenia gravis thymus: roles of IL-17 and TNF-alpha. J Autoimmun. (2014) 52:5363. doi: 10.1016/j.jaut.2013.12.015

30. Fattorossi A, Battaglia A, Buzzonetti A, Ciaraffa F, Scambia G, Evoli A. Circulating and thymic CD4 CD25 T regulatory cells in myasthenia gravis: effect of immunosuppressive treatment. Immunology. (2005) 116:13441. doi: 10.1111/j.1365-2567.2005.02220.x

31. Cohen-Kaminsky S, Levasseur P, Binet JP, Berrih-Aknin S. Evidence of enhanced recombinant interleukin-2 sensitivity in thymic lymphocytes from patients with myasthenia gravis: possible role in autoimmune pathogenesis. J. Neuroimmunol. (1989) 24:75-85. doi: 10.1016/0165-5728(89)90101-X

32. Balandina A, Lécart S, Dartevelle P, Saoudi A, Berrih-Aknin S. Functional defect of regulatory $\mathrm{CD} 4+\mathrm{CD} 25+\mathrm{T}$ cells in the thymus of patients with autoimmune myasthenia gravis. Blood. (2005) 105:735-41. doi: 10.1182/blood-2003-11-3900

33. Aricha R, Reuveni D, Fuchs S, Souroujon MC. Suppression of experimental autoimmune myasthenia gravis by autologous $\mathrm{T}$ regulatory cells. $J$ Autoimmun. (2016) 67:57-64. doi: 10.1016/j.jaut.2015.09.005

34. Aricha R, Feferman T, Fuchs S, Souroujon MC. Ex vivo generated regulatory $\mathrm{T}$ cells modulate experimental autoimmune myasthenia gravis. J. Immunol. (2008) 180:2132-9. doi: 10.4049/jimmunol.180.4.2132

35. Alahgholi-Hajibehzad M, Oflazer P, Aysal F, Durmus H, Gulsen-Parman Y, Marx A, et al. Regulatory function of $\mathrm{CD} 4+\mathrm{CD} 25++\mathrm{T}$ cells in patients with myasthenia gravis is associated with phenotypic changes and STAT5 signaling: 1,25-Dihydroxyvitamin D3 modulates the suppressor activity. $J$ Neuroimmunol. (2015) 281:51-60. doi: 10.1016/j.jneuroim.2015.03.008

36. Sun F, Ladha SS, Yang L, Liu Q, Shi SX, Su N, et al. Interleukin-10 producing-B cells and their association with responsiveness to rituximab in myasthenia gravis. Muscle Nerve. (2014) 49:487-94. doi: 10.1002/mus. 23951

37. Wing JB, Tanaka A, Sakaguchi S. Human FOXP3(+) regulatory T cell heterogeneity and function in autoimmunity and cancer. Immunity. (2019) 50:302-16. doi: 10.1016/j.immuni.2019.01.020

38. Josefowicz SZ, Lu LF, Rudensky AY. Regulatory T cells: mechanisms of differentiation and function. Annu Rev Immunol. (2012) 30:53164. doi: 10.1146/annurev.immunol.25.022106.141623

39. Georgiev $\mathrm{P}$, Charbonnier LM, Chatila TA. Regulatory $\mathrm{T}$ cells: the many faces of Foxp3. J Clin Immunol. (2019) 39:62340. doi: 10.1007/s10875-019-00684-7

40. Rosser EC, Mauri C. Regulatory B cells: origin, phenotype, and function. Immunity. (2015) 42:607-12. doi: 10.1016/j.immuni.2015.04.005

41. Gross CC, Schulte-Mecklenbeck A, Wiendl H, Marcenaro E, Kerlero de Rosbo N, Uccelli A, et al. Regulatory functions of natural killer cells in multiple sclerosis. Front Immunol. (2016) 7:606. doi: 10.3389/fimmu.2016.00606

42. Lunemann A, Lunemann JD, Munz C. Regulatory NK-cell functions in inflammation and autoimmunity. Mol Med. (2009) 15:352-8. doi: 10.2119/molmed.2009.00035

43. Schuster IS, Coudert JD, Andoniou CE, Degli-Esposti MA. "Natural Regulators": NK cells as modulators of T cell immunity. Front Immunol. (2016) 7:235. doi: 10.3389/fimmu.2016.00235

44. Gabrilovich DI. Myeloid-derived suppressor cells. Cancer Immunol Res. (2017) 5:3-8. doi: 10.1158/2326-6066.CIR-16-0297

45. Gabrilovich DI, Nagaraj S. Myeloid-derived suppressor cells as regulators of the immune system. Nat Rev Immunol. (2009) 9:162-74. doi: $10.1038 /$ nri2506

46. Marvel D, Gabrilovich DI. Myeloid-derived suppressor cells in the tumor microenvironment: expect the unexpected. J Clin Invest. (2015) 125:335664. doi: $10.1172 / J C I 80005$

47. Veglia F, Perego M, Gabrilovich D. Myeloid-derived suppressor cells coming of age. Nat Immunol. (2018) 19:108-19. doi: 10.1038/s41590-017-0022-x
48. Gordon JR, Ma Y, Churchman L, Gordon SA, Dawicki W. Regulatory dendritic cells for immunotherapy in immunologic diseases. Front Immunol. (2014) 5:7. doi: 10.3389/fimmu.2014.00007

49. Schmidt SV, Nino-Castro AC, Schultze JL. Regulatory dendritic cells: there is more than just immune activation. Front Immunol. (2012) 3:274. doi: 10.3389/fimmu.2012.00274

50. Zhang Q, Fujino M, Iwasaki S, Hirano H, Cai S, Kitajima Y, et al. Generation and characterization of regulatory dendritic cells derived from murine induced pluripotent stem cells. Sci Rep. (2014) 4:3979. doi: $10.1038 /$ srep03979

51. Chandrasekaran P, Izadjoo S, Stimely J, Palaniyandi S, Zhu X, Tafuri W, et al. Regulatory macrophages inhibit alternative macrophage activation and attenuate pathology associated with fibrosis. J Immunol. (2019) 203:213040. doi: 10.4049 /jimmunol.1900270

52. Fleming BD, Mosser DM. Regulatory macrophages: setting the threshold for therapy. Eur J Immunol. (2011) 41:2498-502. doi: 10.1002/eji.201141717

53. Manjili MH, Wang XY, Abrams S. Evolution of our understanding of myeloid regulatory cells: from MDSCs to Mregs. Front Immunol. (2014) 5:303. doi: $10.3389 /$ fimmu. 2014.00303

54. Zemans RL. Neutrophil-mediated T-cell suppression in influenza: novel finding raising additional questions. Am J Respir Cell Mol Biol. (2018) 58:423-5. doi: 10.1165/rcmb.2017-0425ED

55. Hao S, Andersen M, Yu H. Detection of immune suppressive neutrophils in peripheral blood samples of cancer patients. Am J Blood Res. (2013) 3:239-45.

56. Aarts CEM, Hiemstra IH, Tool ATJ, van den Berg TK, Mul E, van Bruggen $\mathrm{R}$, et al. Neutrophils as suppressors of $\mathrm{T}$ cell proliferation: does age matter? Front Immunol. (2019) 10:2144. doi: 10.3389/fimmu.2019.02144

57. Leliefeld PH, Koenderman L, Pillay J. How neutrophils shape adaptive immune responses. Front Immunol. (2015) 6:471. doi: 10.3389/fimmu.2015.00471

58. Arnold IC, Artola-Boran M, Tallon de Lara P, Kyburz A, Taube C, Ottemann $\mathrm{K}$, et al. Eosinophils suppress Th1 responses and restrict bacterially induced gastrointestinal inflammation. J Exp Med. (2018) 215:205572. doi: $10.1084 /$ jem. 20172049

59. Lingblom C, Andersson J, Andersson K, Wenneras C. Regulatory eosinophils suppress T cells partly through galectin-10. J Immunol. (2017) 198:467281. doi: 10.4049/jimmunol.1601005

60. Rodriguez-Perea AL, Arcia ED, Rueda CM, Velilla PA. Phenotypical characterization of regulatory $\mathrm{T}$ cells in humans and rodents. Clin Exp Immunol. (2016) 185:281-91. doi: 10.1111/cei.12804

61. Miyara M, Chader D, Sage E, Sugiyama D, Nishikawa H, Bouvry D, et al. Sialyl Lewis $\mathrm{x}$ (CD15s) identifies highly differentiated and most suppressive FOXP3high regulatory T cells in humans. Proc Natl Acad Sci USA. (2015) 112:7225-30. doi: 10.1073/pnas.1508224112

62. Geraldes L, Morgado J, Almeida A, Todo-Bom A, Santos P, Paiva A, et al. Expression Patterns of HLA-DR+ or HLA-DR- on $\mathrm{CD} 4+/ \mathrm{CD} 25++/ \mathrm{CD} 127$ low regulatory $\mathrm{T}$ cells in patients with allergy. J Investig Allergol Clin Immunol. (2010) 20:201-9.

63. Booth NJ, McQuaid AJ, Sobande T, Kissane S, Agius E, Jackson SE, et al. Different proliferative potential and migratory characteristics of human $\mathrm{CD} 4+$ regulatory $\mathrm{T}$ cells that express either CD45RA or CD45RO. $J$ Immunol. (2010) 184:4317-26. doi: 10.4049/jimmunol.0903781

64. Yu N, Li X, Song W, Li D, Yu D, Zeng X, et al. CD4(+)CD25 (+)CD127 (low/-) T cells: a more specific Treg population in human peripheral blood. Inflammation. (2012) 35:1773-80. doi: 10.1007/s10753-012-9496-8

65. Miyara M, Yoshioka Y, Kitoh A, Shima T, Wing K, Niwa A, et al. Functional delineation and differentiation dynamics of human CD4+ T cells expressing the FoxP3 transcription factor. Immunity. (2009) 30:899911. doi: 10.1016/j.immuni.2009.03.019

66. Saito T, Nishikawa H, Wada H, Nagano Y, Sugiyama D, Atarashi K, et al. Two FOXP3(+)CD4(+) T cell subpopulations distinctly control the prognosis of colorectal cancers. Nat Med. (2016) 22:679-84. doi: 10.1038/nm.4086

67. Garden OA, Pinheiro D, Cunningham F. All creatures great and small: regulatory T cells in mice, humans, dogs and other domestic animal species. Int Immunopharmacol. (2011) 11:576-88. doi: 10.1016/j.intimp.2010.11.003

68. Wu Y, Chang YM, Stell AJ, Priestnall SL, Sharma E, Goulart MR, et al. Phenotypic characterisation of regulatory $\mathrm{T}$ cells in dogs reveals 
signature transcripts conserved in humans and mice. Sci Rep. (2019) 9:13478. doi: 10.1038/s41598-019-50065-8

69. Pinheiro D, Singh Y, Grant CR, Appleton RC, Sacchini F, Walker KR, et al. Phenotypic and functional characterization of a CD4(+) CD25(high) FOXP3(high) regulatory T-cell population in the dog. Immunology. (2011) 132:111-22. doi: 10.1111/j.1365-2567.2010.03346.x

70. Miller MM, Petty CS, Tompkins MB, Fogle JE. CD4+CD25+ T regulatory cells activated during feline immunodeficiency virus infection convert $\mathrm{T}$ helper cells into functional suppressors through a membrane-bound TGF $\beta$ / GARP-mediated mechanism. Virol J. (2014) 11:7. doi: 10.1186/1743-422X-11-7

71. Mikkelsen SR, Reckling SK, Egan EA, Dean GA. In vivo depletion of CD4(+)CD25(hi) regulatory $\mathrm{T}$ cells is associated with improved antiviral responses in cats chronically infected with feline immunodeficiency virus. Virology. (2010) 403:163-72. doi: 10.1016/j.virol.2010.04.016

72. Vahlenkamp TW, Tompkins MB, Tompkins WA. Feline immunodeficiency virus infection phenotypically and functionally activates immunosuppressive CD4+CD25+ T regulatory cells. J Immunol. (2004) 172:4752-61. doi: 10.4049/jimmunol.172.8.4752

73. Pinheiro D, Chang YM, Bryant H, Szladovits B, Dalessandri T, Davison LJ, et al. Dissecting the regulatory microenvironment of a large animal model of non-hodgkin lymphoma: evidence of a negative prognostic impact of FOXP3 + T cells in canine B cell lymphoma. PLoS ONE. (2014) 9:e105027. doi: 10.1371/journal.pone.0105027

74. Swann JW, Woods K, Wu Y, Glanemann B, Garden OA. Characterisation of the immunophenotype of dogs with primary immune-mediated haemolytic anaemia. PLoS ONE. (2016) 11:e0168296. doi: 10.1371/journal.pone.0168296

75. Alvarez CE. Naturally occurring cancers in dogs: insights for translational genetics and medicine. ILAR J. (2014) 55:16-45. doi: 10.1093/ilar/ilu010

76. Hytonen MK, Lohi H. Canine models of human rare disorders. Rare Dis. (2016) 4:e1241362. doi: 10.1080/21675511.2016.1241362

77. Ito D, Frantz AM, Modiano JF. Canine lymphoma as a comparative model for human non-Hodgkin lymphoma: recent progress and applications. Vet Immunol Immunopathol. (2014) 159:192-201. doi: 10.1016/j.vetimm.2014.02.016

78. Schiffman JD, Breen M. Comparative oncology: what dogs and other species can teach us about humans with cancer. Philos Trans R Soc Lond B Biol Sci. (2015) 370: 20140231. doi: 10.1098/rstb.2014.0231

79. Shearin AL, Ostrander EA. Leading the way: canine models of genomics and disease. Dis Model Mech. (2010) 3:27-34. doi: 10.1242/dmm.004358

80. Machicote A, Belen S, Baz P, Billordo LA, Fainboim L. Human CD8(+)HLA$\mathrm{DR}(+)$ regulatory $\mathrm{T}$ cells, similarly to classical CD4(+)Foxp3(+) cells, suppress immune responses via PD-1/PD-L1 axis. Front Immunol. (2018) 9:2788. doi: 10.3389/fimmu.2018.02788

81. Wang RF. CD8+ regulatory $\mathrm{T}$ cells, their suppressive mechanisms, and regulation in cancer. Hum Immunol. (2008) 69:8114. doi: 10.1016/j.humimm.2008.08.276

82. Zhang S, Wu M, Wang F. Immune regulation by $\mathrm{CD} 8(+)$ Treg cells: novel possibilities for anticancer immunotherapy. Cell Mol Immunol. (2018) 15:805-7. doi: 10.1038/cmi.2018.170

83. Brockmann L, Soukou S, Steglich B, Czarnewski P, Zhao L, Wende $S$, et al. Molecular and functional heterogeneity of IL-10-producing CD4(+) T cells. Nat Commun. (2018) 9:5457. doi: 10.1038/s41467-01807581-4

84. Gagliani N, Magnani CF, Huber S, Gianolini ME, Pala M, Licona-Limon P, et al. Coexpression of CD49b and LAG-3 identifies human and mouse T regulatory type 1 cells. Nat Med. (2013) 19:739-46. doi: 10.1038/nm.3179

85. Li X, Kang N, Zhang X, Dong X, Wei W, Cui L, et al. Generation of human regulatory gammadelta $\mathrm{T}$ cells by TCRgammadelta stimulation in the presence of TGF-beta and their involvement in the pathogenesis of systemic lupus erythematosus. J Immunol. (2011) 186:6693-700. doi: 10.4049/jimmunol.1002776

86. Wesch D, Peters C, Siegers GM. Human gamma delta T regulatory cells in cancer: fact or fiction? Front Immunol. (2014) 5:598. doi: 10.3389/fimmu.2014.00598

87. Krovi SH, Gapin L. Invariant natural killer $\mathrm{T}$ cell subsets-more than just developmental intermediates. Front Immunol. (2018) 9:1393. doi: 10.3389/fimmu.2018.01393
88. Lam PY, Nissen MD, Mattarollo SR. Invariant natural killer $\mathrm{T}$ cells in immune regulation of blood cancers: harnessing their potential in immunotherapies. Front Immunol. (2017) 8:1355. doi: 10.3389/fimmu.2017.01355

89. Sharabi A, Tsokos MG, Ding Y, Malek TR, Klatzmann D, Tsokos GC. Regulatory T cells in the treatment of disease. Nat Rev Drug Discov. (2018) 17:823-44. doi: 10.1038/nrd.2018.148

90. Fontenot JD, Gavin MA, Rudensky AY. Foxp3 programs the development and function of CD4+CD25+ regulatory T cells. Nat Immunol. (2003) 4:330-6. doi: 10.1038/ni904

91. Hori S, Nomura T, Sakaguchi S. Control of regulatory $\mathrm{T}$ cell development by the transcription factor Foxp3. Science. (2003) 299:1057-61. doi: 10.1126/science. 1079490

92. Rudensky AY. Regulatory T cells and Foxp3. Immunol Rev. (2011) 241:260 8. doi: 10.1111/j.1600-065X.2011.01018.x

93. Valencia X, Stephens G, Goldbach-Mansky R, Wilson M, Shevach EM, Lipsky PE. TNF downmodulates the function of human CD4CD25hi T-regulatory cells. Blood. (2006) 108:253-61. doi: 10.1182/blood-2005-11-4567

94. Gao Y, Tang J, Chen W, Li Q, Nie J, Lin F, et al. Inflammation negatively regulates FOXP3 and regulatory T-cell function via DBC1. Proc Natl Acad Sci USA. (2015) 112:E3246-E54. doi: 10.1073/pnas.1421463112

95. Yi JS, Guidon A, Sparks S, Osborne R, Juel VC, Massey JM, et al. Characterization of CD4 and CD8 T cell responses in MuSK myasthenia gravis. J Autoimmun. (2014) 52:130-8. doi: 10.1016/j.jaut.2013.12.005

96. Li Y, Guptill JT, Russo MA, Massey JM, Juel VC, Hobson-Webb LD, et al. Tacrolimus inhibits Th1 and Th17 responses in MuSKantibody positive myasthenia gravis patients. Exp Neurol. (2019) 312:4350. doi: 10.1016/j.expneurol.2018.11.006

97. Reuveni D, Aricha R, Souroujon MC, Fuchs S. MuSK EAMG: immunological characterization and suppression by induction of oral tolerance. Front Immunol. (2020) 11:403. doi: 10.3389/fimmu.2020.00403

98. Shen E, Rabe H, Luo L, Wang L, Wang Q, Yin J, et al. Control of germinal center localization and lineage stability of follicular regulatory $\mathrm{T}$ cells by the blimp1 transcription factor. Cell Rep. (2019) 29:184861.e6. doi: 10.1016/j.celrep.2019.10.012

99. Xie MM, Fang S, Chen Q, Liu H, Wan J, Dent AL. Follicular regulatory T cells inhibit the development of granzyme B-expressing follicular helper $\mathrm{T}$ cells. JCI Insight. (2019) 4:e128076. doi: 10.1172/jci.insight.128076

100. Huang Y, Chen Z, Wang H, Ba X, Shen P, Lin W, et al. Follicular regulatory T cells: a novel target for immunotherapy? Clin Transl Immunology. (2020) 9:e1106. doi: 10.1002/cti2.1106

101. Xie MM, Dent AL. Unexpected help: follicular regulatory $\mathrm{T}$ cells in the germinal center. Front Immunol. (2018) 9:1536. doi: 10.3389/fimmu.2018.01536

102. Crotty S. T Follicular helper cell differentiation, function, and roles in disease. Immunity. (2014) 41:529-42. doi: 10.1016/j.immuni.2014.10.004

103. Crotty S. T Follicular helper cell biology: a decade of discovery and diseases. Immunity. (2019) 50:1132-48. doi: 10.1016/j.immuni.2019.04.011

104. Maceiras AR, Almeida SCP, Mariotti-Ferrandiz E, Chaara W, Jebbawi F, Six A, et al. T follicular helper and T follicular regulatory cells have different TCR specificity. Nat Commun. (2017) 8:15067. doi: 10.1038/ncomms15067

105. Wang X, Yang C, Xu F, Qi L, Wang J, Yang P. Imbalance of circulating $\mathrm{Tfr} / \mathrm{Tfh}$ ratio in patients with rheumatoid arthritis. Clin Exp Med. (2019) 19:55-64. doi: 10.1007/s10238-018-0530-5

106. Liang M, Liwen Z, Juan D, Yun Z, Yanbo D, Jianping C. Dysregulated TFR and TFH cells correlate with B-cell differentiation and antibody production in autoimmune hepatitis. J Cell Mol Med. (2020) 24:394857. doi: 10.1111/jcmm.14997

107. Wen Y, Yang B, Lu J, Zhang J, Yang H, Li J. Imbalance of circulating CD4(+)CXCR5(+)FOXP3 $(+)$ Tfr-like cells and CD4(+)CXCR5(+)FOXP3(-) Tfh-like cells in myasthenia gravis. Neurosci Lett. (2016) 630:176-82. doi: 10.1016/j.neulet.2016.07.049

108. Cebi M, Durmus H, Aysal F, Ozkan B, Gul GE, Cakar A, et al. CD4(+) T cells of myasthenia gravis patients are characterized by increased IL-21, IL-4, and IL-17A productions and higher presence of PD-1 and ICOS. Front Immunol. (2020) 11:809. doi: 10.3389/fimmu.2020.00809

109. Saito R, Onodera H, Tago H, Suzuki Y, Shimizu M, Matsumura $\mathrm{Y}$, et al. Altered expression of chemokine receptor CXCR5 on $\mathrm{T}$ 
cells of myasthenia gravis patients. J Neuroimmunol. (2005) 170:1728. doi: 10.1016/j.jneuroim.2005.09.001

110. Luo C, Li Y, Liu W, Feng H, Wang H, Huang X, et al. Expansion of circulating counterparts of follicular helper T cells in patients with myasthenia gravis. $J$ Neuroimmunol. (2013) 256:55-61. doi: 10.1016/j.jneuroim.2012.12.001

111. Xin N, Fu L, Shao Z, Guo M, Zhang X, Zhang Y, et al. RNA interference targeting Bcl-6 ameliorates experimental autoimmune myasthenia gravis in mice. Mol Cell Neurosci. (2014) 58:85-94. doi: 10.1016/j.mcn.2013.12.006

112. Berrih-Aknin S. Imbalance between $\mathrm{T}$ follicular helper and $\mathrm{T}$ follicular regulatory cells in myasthenia gravis. J Xiangya Med. (2017) 2:22. doi: $10.21037 / j x y m .2017 .02 .06$

113. Zhang CJ, Gong Y, Zhu W, Qi Y, Yang CS, Fu Y, et al. Augmentation of circulating follicular helper $\mathrm{T}$ cells and their impact on autoreactive B cells in myasthenia gravis. J Immunol. (2016) 197:2610-7. doi: 10.4049/jimmunol.1500725

114. Li Y, Guptill JT, Russo MA, Howard JF, Massey JM, Juel VC, et al. Imbalance in $\mathrm{T}$ follicular helper cells producing IL-17 promotes pro-inflammatory responses in MuSK antibody positive myasthenia gravis. J Neuroimmunol. (2020) 345:577279. doi: 10.1016/j.jneuroim.2020.577279

115. Goulart MR, Hlavaty SI, Chang YM, Polton G, Stell A, Perry J, et al. Phenotypic and transcriptomic characterization of canine myeloid-derived suppressor cells. Sci Rep. (2019) 9:3574. doi: 10.1038/s41598-019-40285-3

116. Whitfield-Larry F, Felton J, Buse J, Su MA. Myeloid-derived suppressor cells are increased in frequency but not maximally suppressive in peripheral blood of Type 1 diabetes mellitus patients. Clin Immunol. (2014) 153:15664. doi: 10.1016/j.clim.2014.04.006

117. Kurkó J, Vida A, Glant TT, Scanzello CR, Katz RS, Nair A, et al. Identification of myeloid-derived suppressor cells in the synovial fluid of patients with rheumatoid arthritis: a pilot study. BMC Musculoskelet Disord. (2014) 15:281. doi: 10.1186/1471-2474-15-281

118. Jiao Z, Hua S, Wang W, Wang H, Gao J, Wang X. Increased circulating myeloid-derived suppressor cells correlated negatively with Th17 cells in patients with rheumatoid arthritis. Scand J Rheumatol. (2013) 42:8590. doi: $10.3109 / 03009742.2012 .716450$

119. Guo C, Hu F, Yi H, Feng Z, Li C, Shi L, et al. Myeloid-derived suppressor cells have a proinflammatory role in the pathogenesis of autoimmune arthritis. Ann Rheum Dis. (2016) 75:278-85. doi: 10.1136/annrheumdis-2014-205508

120. Fujii W, Ashihara E, Hirai H, Nagahara H, Kajitani N, Fujioka $\mathrm{K}$, et al. Myeloid-derived suppressor cells play crucial roles in the regulation of mouse collagen-induced arthritis. J Immunol. (2013) 191:107381. doi: 10.4049/jimmunol.1203535

121. Egelston C, Kurko J, Besenyei T, Tryniszewska B, Rauch TA, Glant TT, et al. Suppression of dendritic cell maturation and $\mathrm{T}$ cell proliferation by synovial fluid myeloid cells from mice with autoimmune arthritis. Arthritis Rheum. (2012) 64:3179-88. doi: 10.1002/art.34494
122. Boros P, Ochando J, Zeher M. Myeloid derived suppressor cells and autoimmunity. Hum Immunol. (2016) 77:6316. doi: 10.1016/j.humimm.2016.05.024

123. Li Y, Tu Z, Qian S, Fung JJ, Markowitz SD, Kusner LL, et al. Myeloid-derived suppressor cells as a potential therapy for experimental autoimmune myasthenia gravis. J Immunol. (2014) 193:2127-34. doi: 10.4049/jimmunol.1400857

124. Peng B, Ming Y, Yang C. Regulatory B cells: the cutting edge of immune tolerance in kidney transplantation. Cell Death Dis. (2018) 9:109. doi: 10.1038/s41419-017-0152-y

125. Yilmaz V, Maillard S, Truffault F, Bolgert F, Behin A, Regnard JF, et al. Regulatory B cells in myasthenia gravis are differentially affected by therapies. Ann Clin Transl Neurol. (2018) 5:1408-14. doi: 10.1002/acn3.645

126. Tedder TF. B10 Cells: a functionally defined regulatory B cell subset. $J$ Immunol. (2015) 194:1395-401. doi: 10.4049/jimmunol.1401329

127. Guptill JT, Yi JS, Sanders DB, Guidon AC, Juel VC, Massey JM, et al. Characterization of $\mathrm{B}$ cells in muscle-specific kinase antibody myasthenia gravis. Neurol Neuroimmunol Neuroinflamm. (2015) 2:e77. doi: 10.1212/NXI.0000000000000077

128. Pennati A, Ng S, Wu Y, Murphy JR, Deng J, Rangaraju S, et al. Regulatory B cells induce formation of IL-10-expressing $\mathrm{T}$ cells in mice with autoimmune neuroinflammation. $J$ Neurosci. (2016) 36:12598-610. doi: 10.1523/JNEUROSCI.199416.2016

129. Dolton G, Zervoudi E, Rius C, Wall A, Thomas HL, Fuller A, et al. Optimized peptide-MHC multimer protocols for detection and isolation of autoimmune T-cells. Front Immunol. (2018) 9:1378. doi: 10.3389/fimmu.2018.01378

130. Bruder D, Probst-Kepper M, Westendorf AM, Geffers R, Beissert S, Loser K, et al. Neuropilin-1: a surface marker of regulatory T cells. Eur J Immunol. (2004) 34:623-30. doi: 10.1002/eji.200324799

131. Ding T, Niu H, Zhao X, Gao C, Li X, Wang C. T-follicular regulatory cells: potential therapeutic targets in rheumatoid arthritis. Front Immunol. (2019) 10:2709. doi: 10.3389/fimmu.2019.02709

Conflict of Interest: The authors declare that the research was conducted in the absence of any commercial or financial relationships that could be construed as a potential conflict of interest.

Copyright (c) $2020 \mathrm{Wu}$, Luo and Garden. This is an open-access article distributed under the terms of the Creative Commons Attribution License (CC BY). The use, distribution or reproduction in other forums is permitted, provided the original author(s) and the copyright owner(s) are credited and that the original publication in this journal is cited, in accordance with accepted academic practice. No use, distribution or reproduction is permitted which does not comply with these terms. 